International Journal of Biology, Pharmacy and Allied Sciences (IJBPAS) 'A Bridge Betuen Caboratory and QRando'

WwW.iibpas.com

\title{
KNOWLEDGE AND AWARENESS ABOUT NANOTECHNOLOGY AND ITS APPLICATIONS IN DENTISTRY- A SURVEY
}

\section{SAMYUKTHA P $\mathrm{S}^{1}$, BALAJI GANESH $\mathrm{S}^{2 *}$ AND SOMASUNDARAM J $\mathrm{J}^{\mathbf{3}}$}

1: Saveetha Dental College and Hospital, Saveetha Institute of Medical and Technical Sciences, Saveetha University, Chennai, India

2: Scientist, White Lab Material Research Centre, Saveetha Dental College and Hospital, Saveetha Institute of Medical and Technical Sciences, Saveetha University, Chennai, India

3: Chief scientist, White Lab- Material research centre, Saveetha Dental College and Hospital, Saveetha Institute of Medical and Technical Sciences, Saveetha University, Chennai, India

*Corresponding Author: E Mail: Dr. Balaji Ganesh S: $\underline{\text { balajiganeshs.sdc@saveetha.com }}$

Received 20 ${ }^{\text {th }}$ March 2021; Revised 26 ${ }^{\text {th }}$ April. 2021; Accepted 24 ${ }^{\text {th }}$ May 2021; Available online $1^{\text {st }}$ Aug. 2021

\section{https://doi.org/10.31032/IJBPAS/2021/10.8.1089}

\section{ABSTRACT}

Nanotechnology refers to the development of an applied science at the molecular or atomic level. The basic idea involved in nanotechnology is to employ individual molecules or atoms to construct functional structures. Nano materials are materials which have components of nano size. The properties of nano materials vary due to increased surface area and quantum properties, which are more dominant at the nanoscale level. All properties, including electrical, optical and magnetic are changed. Nanotechnology has many applications in the medical field and also in dentistry. The survey assesses the knowledge and awareness levels about nanotechnology among dental students. In 2020, an online survey containing 15 questions was sent out to 100 dental students. Results were tabulated and analysed. Overall, there was a positive response from the students about nanotechnology. 95\% believe that nano technology is essential to dentistry. Knowledge about advanced materials is not as worldwide as we are led to believe. The current study shows the lack of specific knowledge in the population that participated. Through the survey, it was evaluated that the students had moderate awareness and knowledge about nanotechnology which can be improved.

Keywords: Dental Nanotechnology, Nanobots, Nanocomposite, Nanomaterials, Nanotechnology 


\section{INTRODUCTION}

Nanotechnology refers to the development of an applied science at the molecular or atomic level. The basic idea involved in nanotechnology is to employ individual molecules or atoms to construct functional structures [1]. Nano materials are materials which have components of nano size. The properties of nano materials vary due to increased surface area and quantum properties, which are more dominant at the nanoscale level. All properties, including electrical, optical and magnetic are changed [2]. Nanotechnology has many applications in the medical field. Nanotechnology has various scopes that are currently being used [3]. Some of the common research scopes studied include Nanorobotics, Nanotherapeutics, Nano-diagnostics, Nanocomposites, Nano Adhesives etc.

Nano robotics is used in local Nanoanesthesia. A colloid and suspension with millions of dental nanorobots are used to induce local anaesthesia. The robots move from the gingiva to the dentine and to the pulp through dentinal tubules [4]. Nanobots are also used in tooth repositioning. All periodontal tissues, namely the gingiva periodontal ligament, cementum and alveolar bone may be directed by orthodontic treatment using nanorobots [5]. Nanotechnology is also used as drug delivery mechanisms in Nanotherapeutics. Nano technology eliminates solubility problems, leading to reduction of drug dosage and adverse effects [6]. Nanotechnology is also used in the diagnosis of oral cancer. Carbon nanotubes can detect affected genes and localise their locations [7]. One of the more clinically prominent uses of Nanotechnology is the incorporation of Nanofillers in nanocomposite. Very minute filler particles result in higher proportions, leading to in distinctive physical, mechanical and optical properties [8]. Bonding agents use Nano adhesives which constitute disposable nanoparticles. These are used as a component in bonding agents [9]. Challenges faced in nanotechnology: Precise positioning and manufacture, Costeffective methods, Biocompatibility, Financing, Inadequate clinical research, Social issues etc.

As nanotechnology is an emerging field, its implications in dentistry increases. Thus, knowledge and awareness about nanotechnology is essential to the students. Previously, our team had conducted numerous clinical trials [10-14], in-vitro studies [15-17], reviews [18-23] and population studies [24] over the past 5 years. Now, we are focusing on epidemiological surveys. The idea for this survey stemmed from the current interest in our community. Hence, the aim of the study was to evaluate the knowledge and 
awareness of dental students in Nanotechnology and its applications in dentistry.

\section{MATERIALS AND METHODS}

The study is an online based cross-sectional survey. Data was collected by circulating a Self structured questionnaire consisting of 16 questions. 100 students were selected based on simple random sampling. This is done to minimise bias.

The results were tabulated and analysed using Windows version SPSS version 20. Frequency and Chi-Square test was done for the data obtained. Pie charts and bar graphs were used to depict the results.

\section{RESULTS AND DISCUSSION}

Analysing the responses, the following results were obtained.

$61 \%$ were aware of the general principles of nanotechnology (Fig. 1). Applications of nano technology contained very results for each application. $90 \%$ of the population were aware about nano robots; $60 \%$ were aware about drug delivery systems; 56\% knew about tooth renaturalisation. The Use of nano materials yielded confused responses. $80 \%$ answered incorrectly regarding use of carbon nanotubes (Fig. 6), $54 \%$ (Fig. 5) answered incorrectly regarding which nanoparticles were safest to use in dentistry, $57 \%$ have not dealt with nano materials (Fig. 2), 95\% were aware of nano adhesive properties, $60 \%$ aware of nano composite bonded teeth, $77 \%$ aware about titanium coated implants. $83 \%$ believe nano materials are biocompatible. $77 \%$ believe that nanotechnology can revolutionise dentistry (Fig. 7), 65\% believe that nanotechnology is essential to dentistry (Fig. 8). The cross tabulations and the $p$ values of the Chi- Square test for the responses were done and the results turned out to be insignificant ( $\mathrm{p}$ value less than 0.05) (Fig. 9 and 10).

Nanotechnology is a very popular and emerging science. It has a promising future. Knowledge and awareness about now technology is thus essential. The first and foremost fact about the technology is that its small size opens are big avenues for the materials [25]. Previous research by Sakr et al in 2018, conducted an extensive survey in Saudi Arabia [26]. It concluded that there is a lack of attention to nanotechnology applications in dentistry among students and students of Saudi Arabia. While a total of $50 \%$ participants had no prior knowledge about our technology, the current study had $68 \%$ correct response (Fig. 1).

The current study is also similar to the previous study. About $26 \%$ of the participants use nano materials clinically. In current study about $45 \%$ had used nano materials clinically (Fig. 2). There are various factors that affect the disparity and similarity, a few which include availability 
of nano materials, knowledge about Nanomaterials et cetera.

The next past research we will be comparing with that of Sara Ali et al in 2017 [27]. The study was conducted in Pakistan and had very simple basic questions in its questionnaire. The study also concluded that there is a lack of awareness on nanotechnology applications. They further concluded that the participants showed enthusiasm in learning about nanotechnology. This is similar to the present study, when $90 \%$ are willing to learn about clinical techniques revolving around nano technology (Fig. 3). There is another fact that binds the two researches. About $29 \%$ of the population had used nano composite prior to this research, in the present study about $45 \%$ had used nano materials. This makes us believe that nano materials, although have shown great properties and research studies, are yet to be incorporated into everyday clinical practice [28]. This brings us to the next point - nano materials are not cost-effective yet (Fig. 4).

A study conducted by Daoutsali et al in 2014, also yielded a similar result [29]. As the technological development is not the same worldwide, there are bound to be discrepancies in management of technologically advanced substances worldwide [30]. The same way, knowledge about advanced materials is not as worldwide as we are led to believe [31]. A Study conducted by Xenaki et al in 2019, shows us that the school or the university curriculum plays a major role in what the individual will know and understand [32]. While the study showed the correct responses to nanotechnology related questions in a huge number - $88 \%$, the current study shows the lack of knowledge in the population (Fig. 5, 6). The study conducted by Ali et al 2017, concurs with our present study in the question of whether nanotechnology can revolutionise dentistry [33] (Fig. 7).

In the end, what decides the impact on the field is whether its students can believe it is vital in it [34]. $95 \%$ of the population agree that nanotechnology is vital in the dental field (Fig. 8). This is an acceptance to the study conducted by Retzbach et al in 2011 [35].

Some of the limitations faced by the study include a small sample size, and the respondents unwillingness to answer. The cross tabulations of the survey was done between Gender and various responses of the questions. The $\mathrm{p}$ value for the Chi- Square Test done for the cross tabulation between Gender and "Do you think Nanotechnology can revolutionise dentistry?" was found to be 0.975 , which is insignificant (Fig. 9). The p value for the Chi- Square Test done for the cross tabulation between Gender and "Do you agree on the essentiality of nanotechnology?" was found to be 0.635, which is insignificant (Fig. 10). 


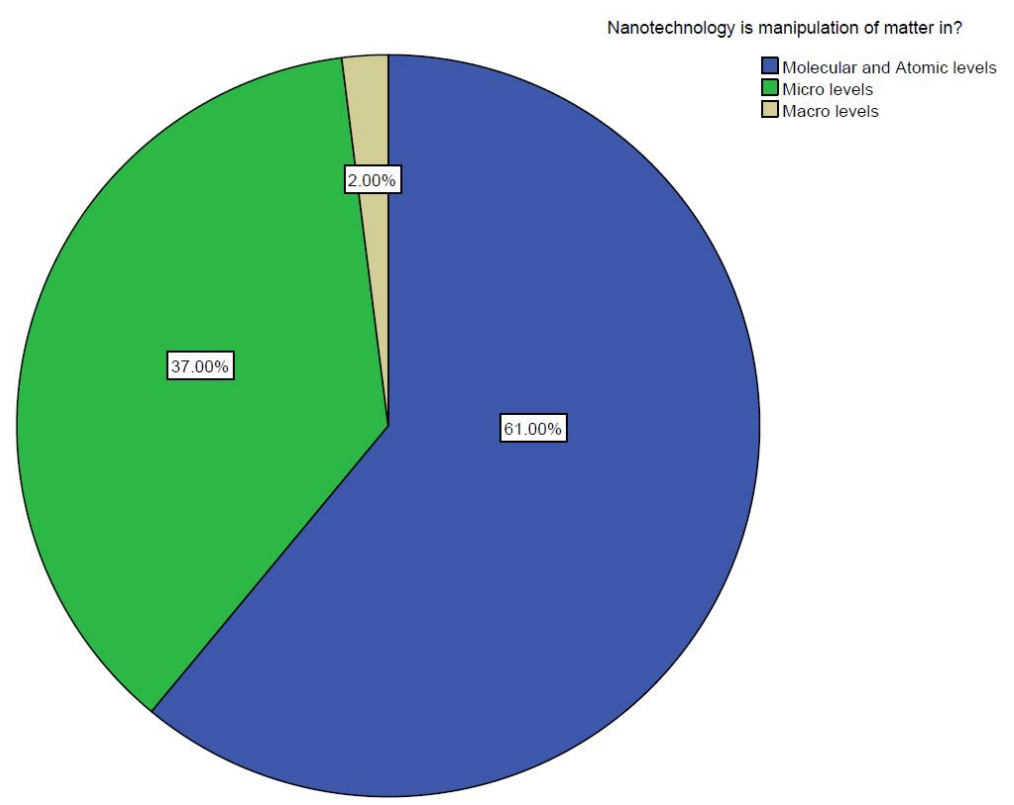

Fig. 1: Pie chart depicting the responses to questions related to the definition of Nanotechnology. $61 \%$ responded with "Molecular and atomic levels" (blue), $2 \%$ responded with "macro levels" (yellow) and $37 \%$ responded with micro levels (green).

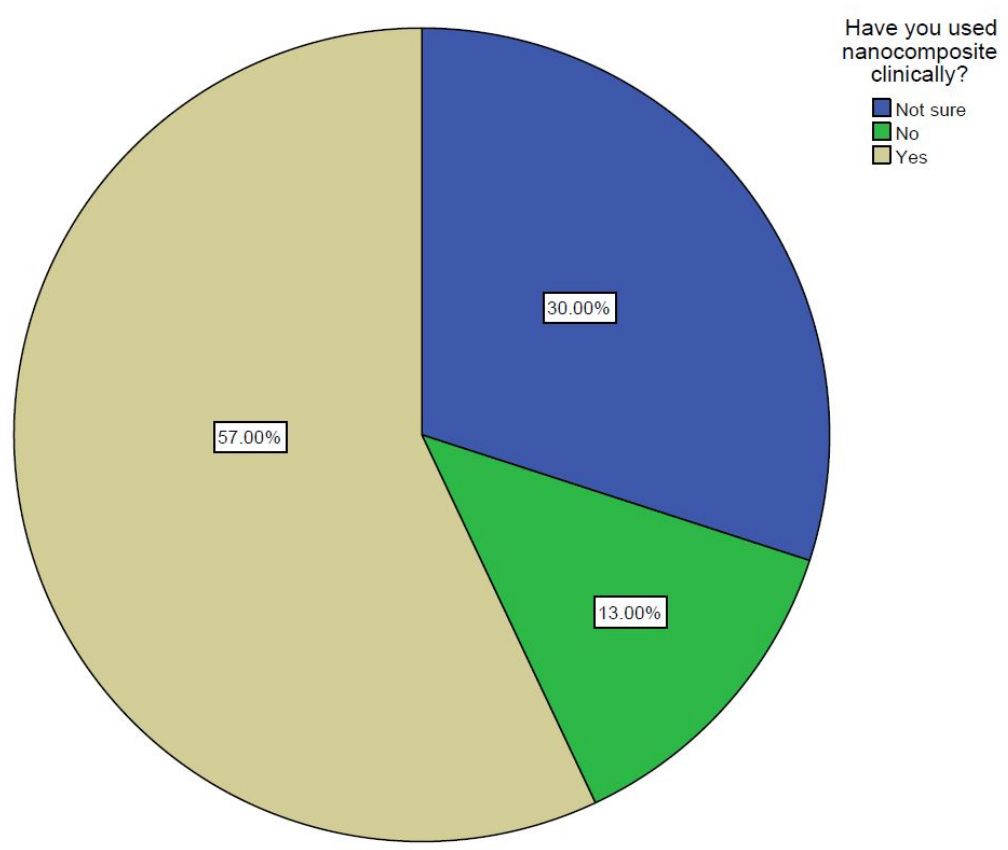

Fig 2: Pie chart depicting the responses related to clinical use of Nanocomposites. $57 \%$ responded positively (yellow), $13 \%$ responded negatively (green) and $30 \%$ responded with "not sure" (blue). 


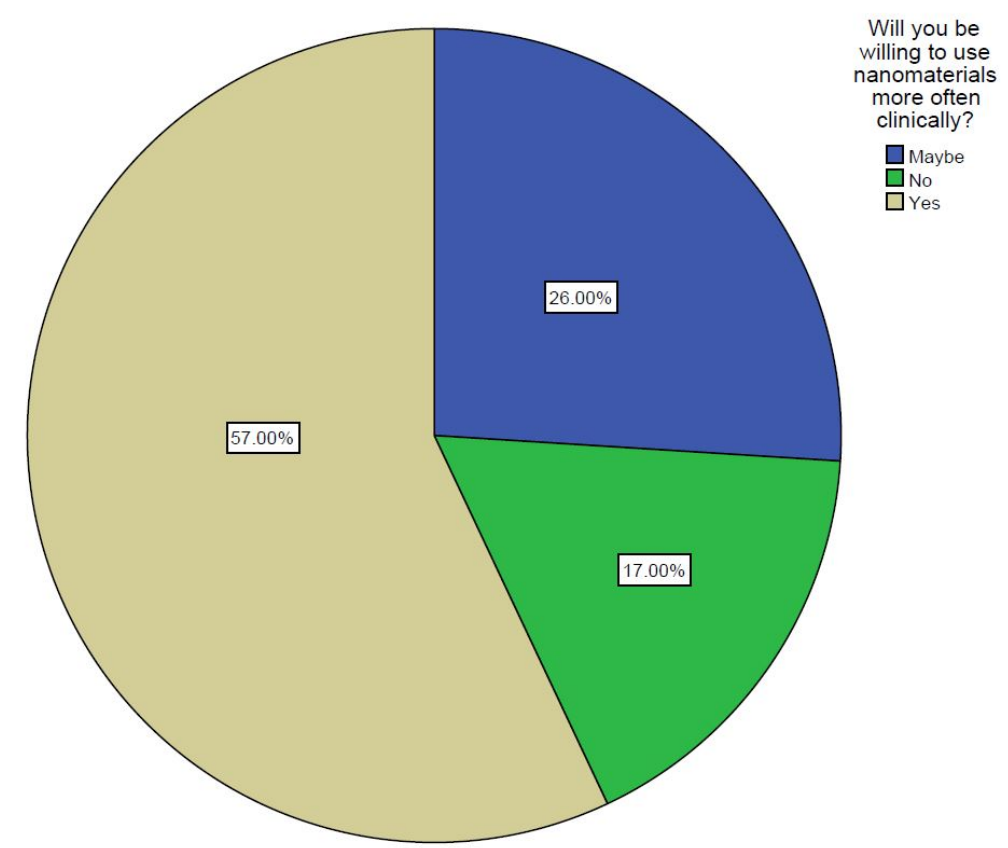

Fig 3: Pie chart depicting the response to the question "Are you willing to learn about Nanomaterials for clinical use?". 57\% responded positively (yellow), $17 \%$ responded negatively (green) and $26 \%$ were not sure (blue).

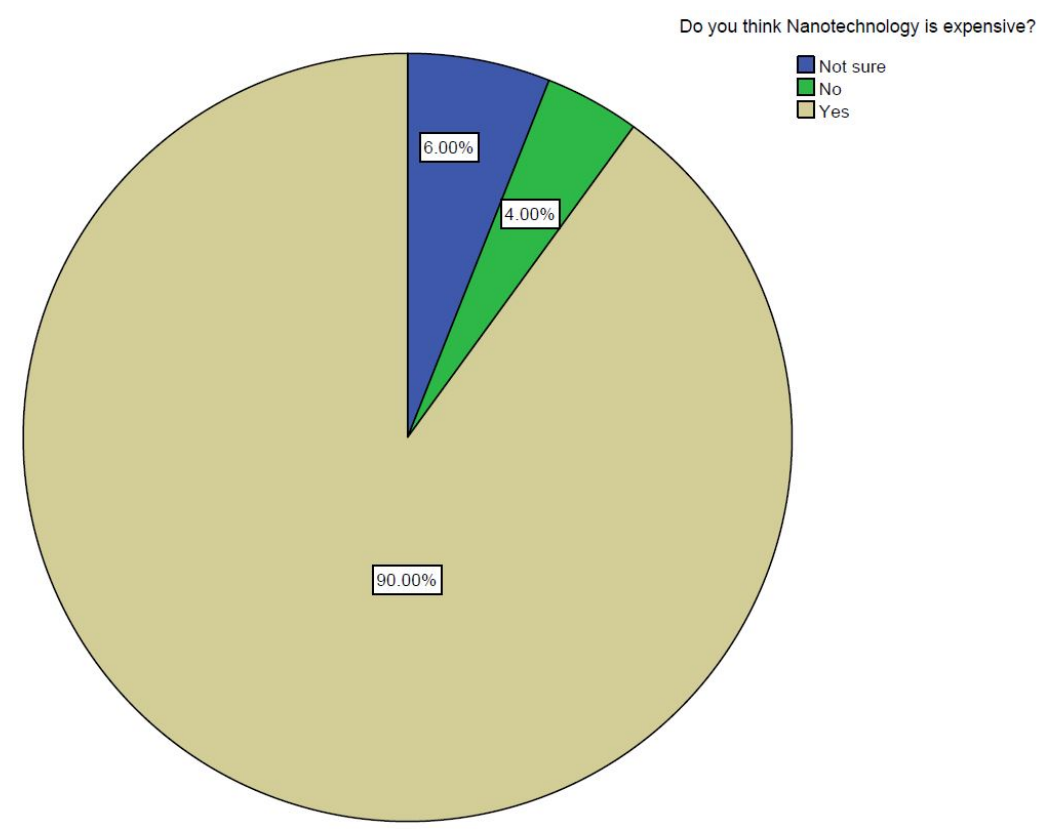

Fig. 4: Pie chart depicting the responses to the question "Do you think nanomaterials are expensive?". $90 \%$ agreed that nanomaterials are expensive (yellow), $4 \%$ disagreed (green) and $6 \%$ were not sure (blue). 


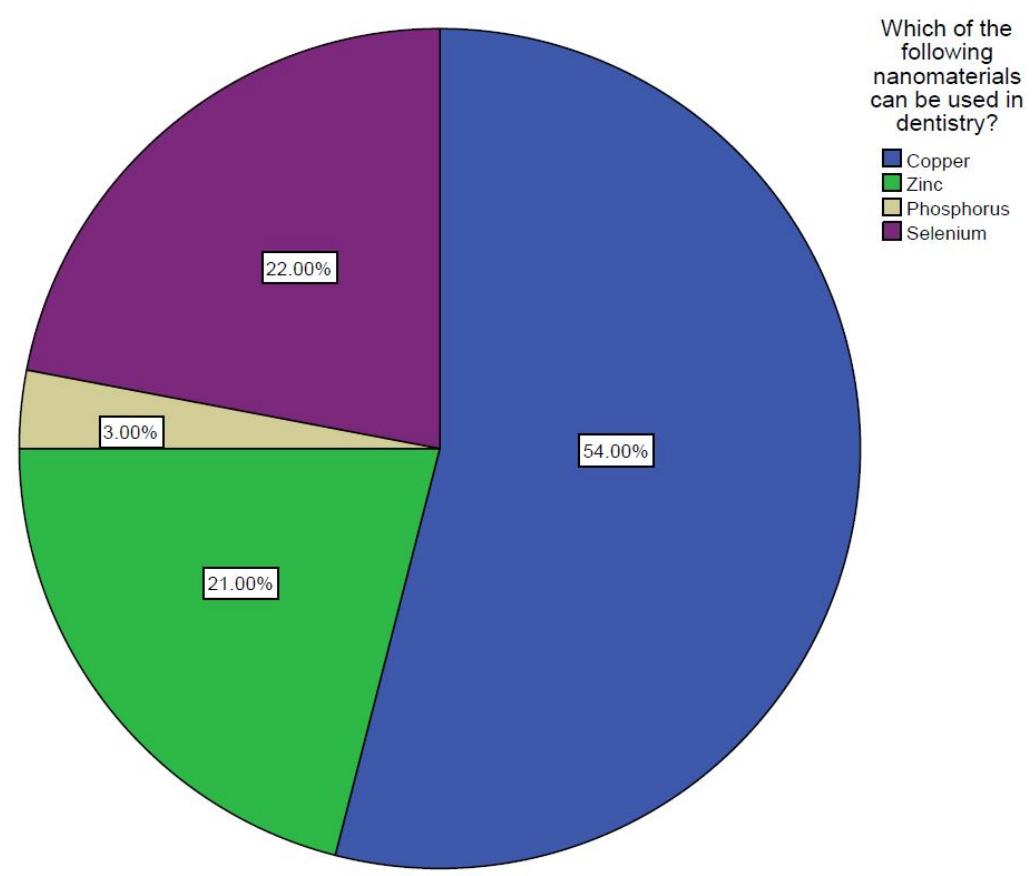

Fig. 5: Pie chart depicting the responses to the question "Which of the following nanoparticles is used clinically". Majority of the answers were incorrect. 54\% responded with "Copper" (blue). The other three nanoparticles have been reported to be used clinically.

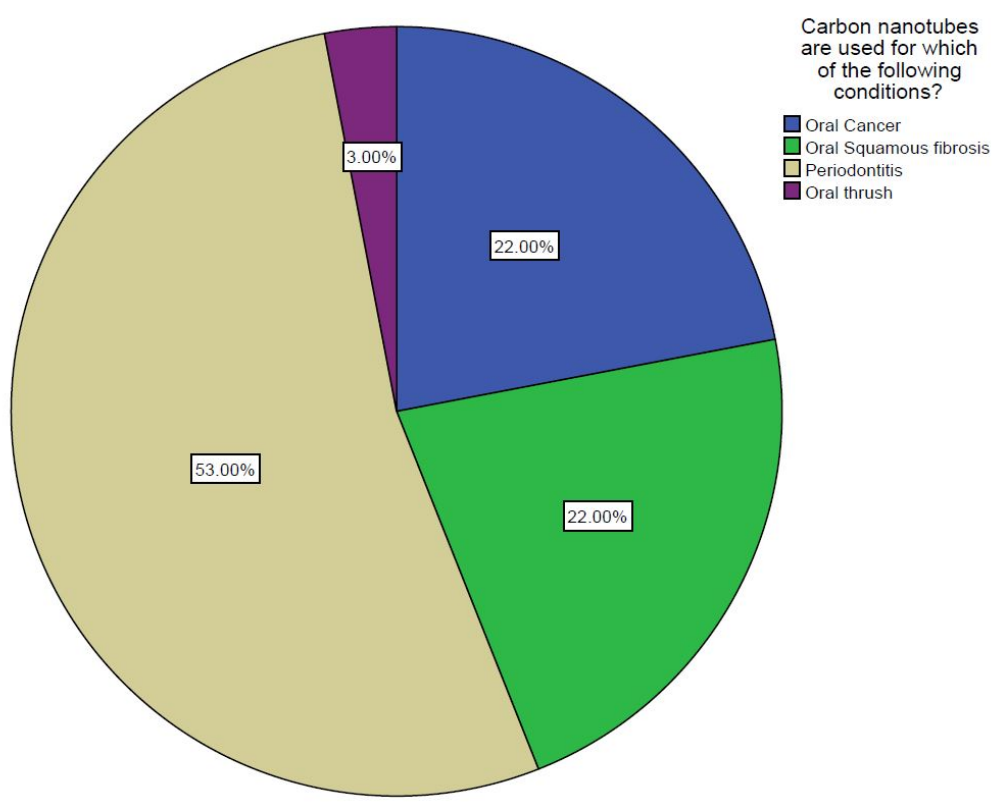

Fig. 6: Pie chart depicting the responses to "Carbon nanotubes are used in the diagnosis of?". The correct answer is Oral Cancer. Only $22 \%$ responded correctly (blue). 


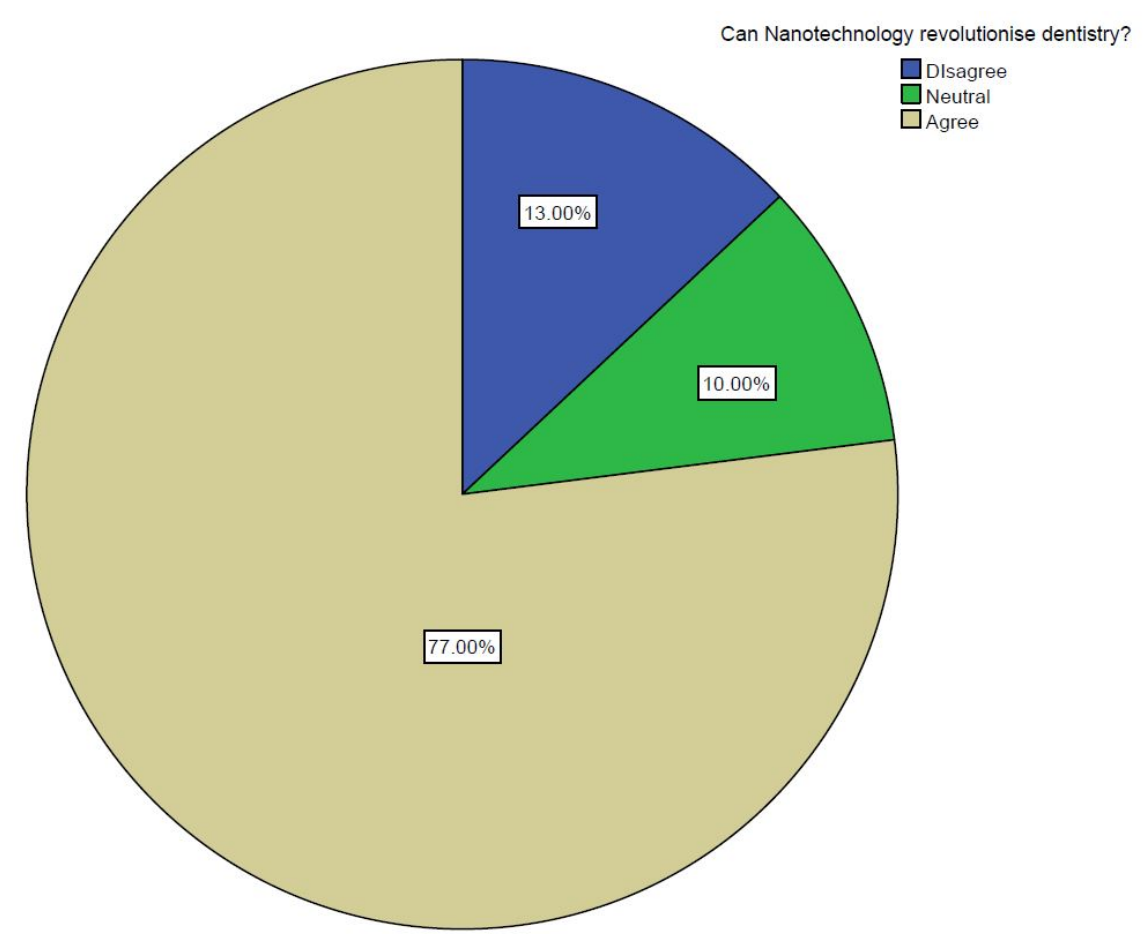

Fig 7: Pie chart depicting the responses to "Do you think Nanotechnology can revolutionise dentistry?" $77 \%$ agreed that nanotechnology will revolutionise dentistry (yellow), 13\% disagreed (blue) and $10 \%$ remained neutral (green).

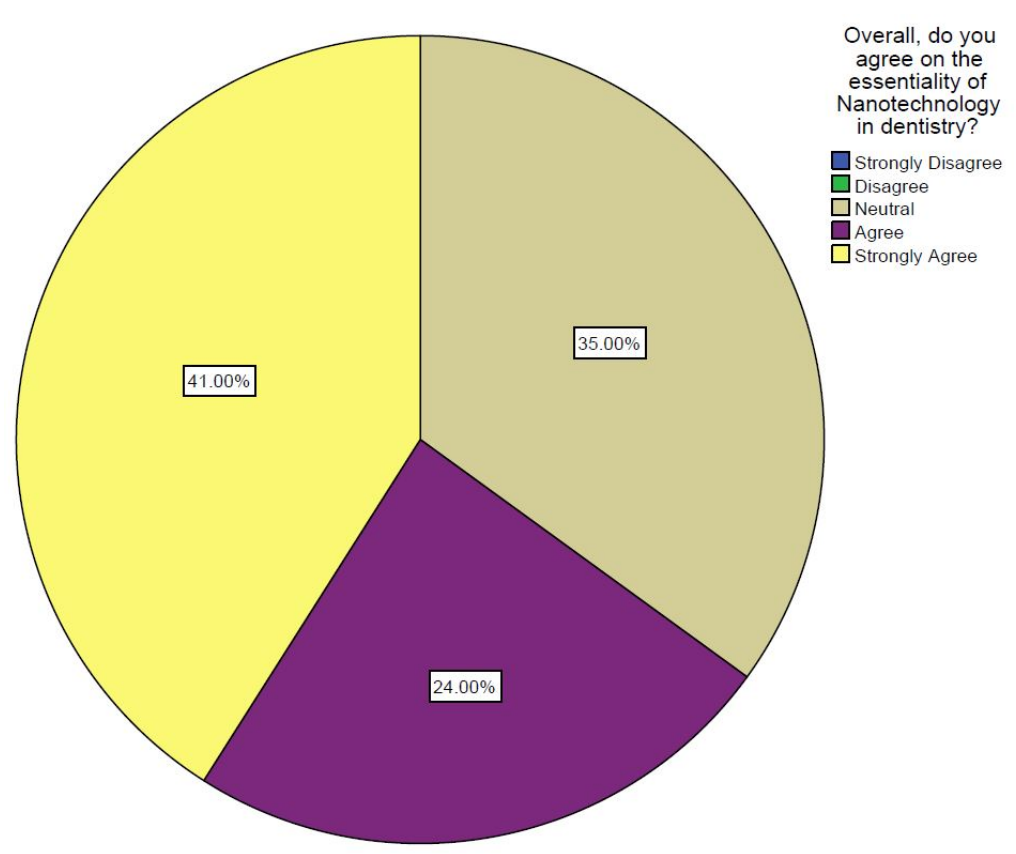

Fig. 8: Pie chart depicting the responses to "Nanotechnology is essential in dentistry". 35\% remained neutral (beige), while 65\% responded with Strongly Agree (yellow) and Agree (purple). 


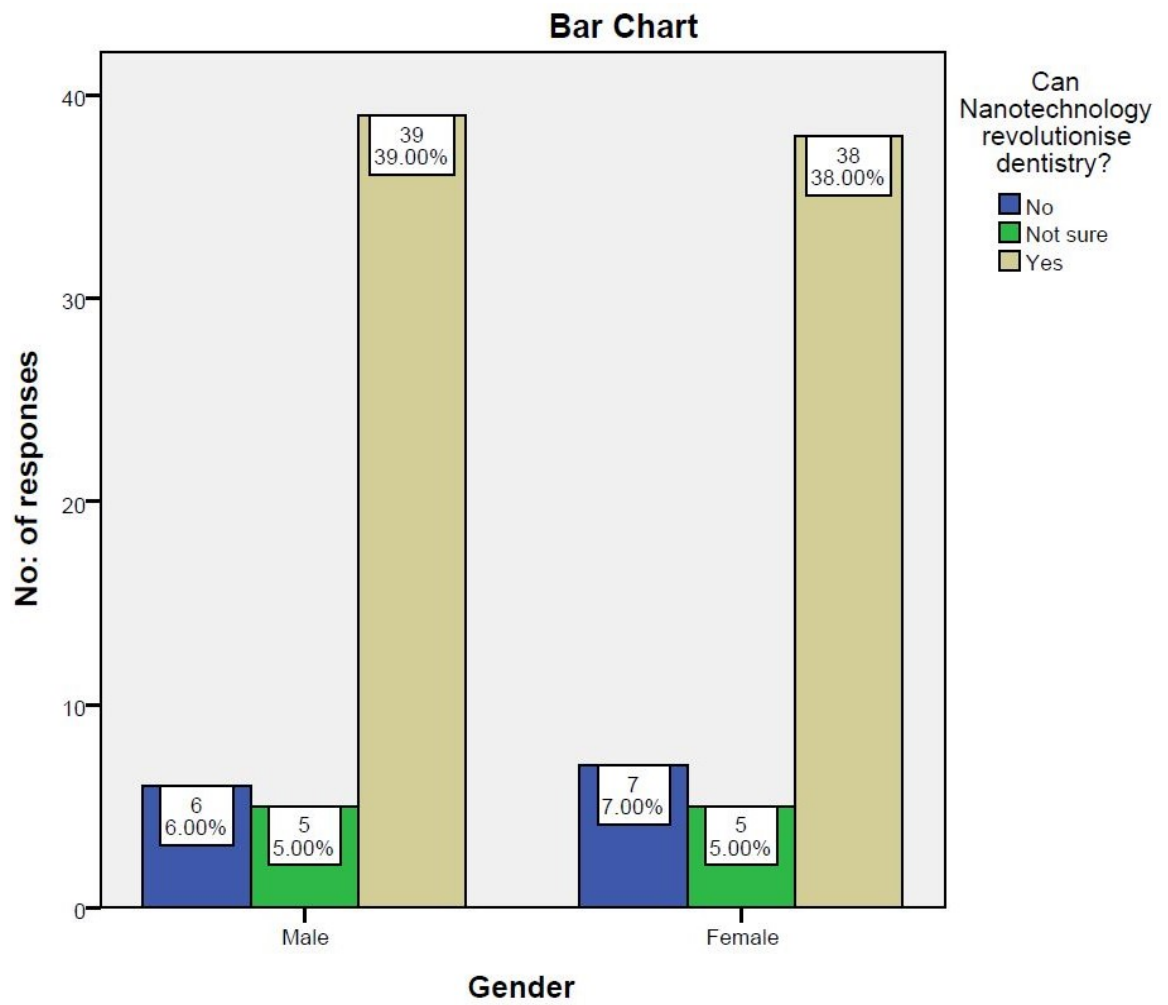

Fig. 9: Bar chart depicting the comparison of responses based on Gender to the question, "Do you think Nanotechnology can revolutionise Dentistry?". X axis represents Gender and Y axis represents the Participants' responses. Almost equal percentage of male and female participants agreed that nanotechnology can revolutionise dentistry. However, Chi-square analysis $($ Chi- square value $=0.050)$ did not show any statistical significance with $p$ value- $0.975(p>0.05)$.

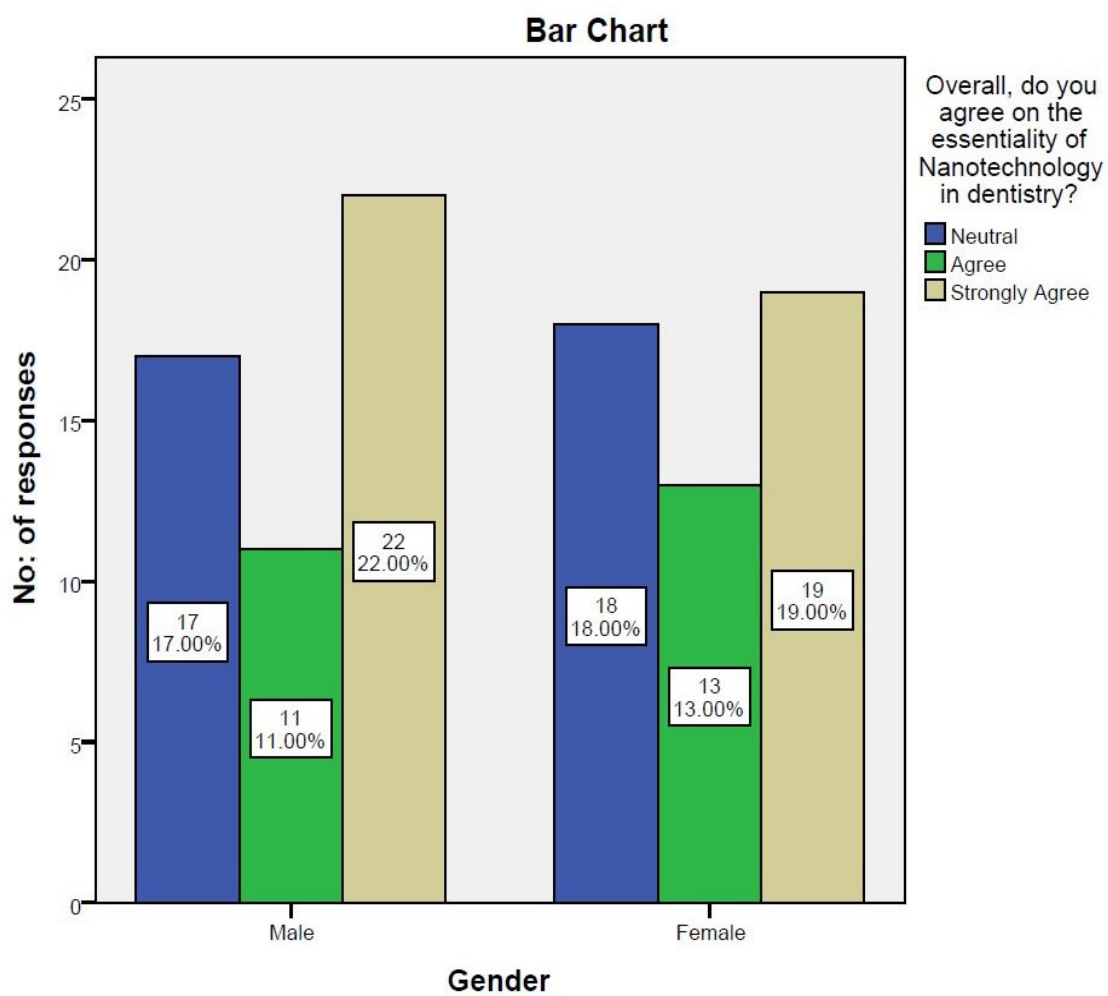

Fig. 10: Bar chart depicting the comparison of responses based on Gender to the question, "Do you agree on the essentiality of Nanotechnology?". X axis represents Gender and Y axis represents the Participants' responses. Almost 
equal percentage of male and female participants agreed that nanotechnology is essential. Chi-square analysis (Chisquare value $=0.909)$ did not show any statistical significance with $p$ value- $0.635(p>0.05)$.

\section{FUTURE SCOPE}

The study can further be expanded by extensive research to develop new nano materials and applications.

\section{CONCLUSION}

Within the limits of the study, the knowledge and awareness about nanotechnology and its applications in dentistry was evaluated. It was found that the dental students had a moderate level of knowledge about nanotechnology in dentistry, which can be improved by delivering information and exposure to the Nano materials used in dentistry.

\section{ACKNOWLEDGEMENT}

The authors are thankful to Saveetha Dental College for providing a platform to express our knowledge.

\section{AUTHOR CONTRIBUTIONS}

Samyuktha P S contributed to data collection, analysis and interpretation and drafting of the article. Balaji Ganesh and Jayalaksmi $\mathrm{S}$ contributed to the critical revision of the article.

\section{CONFLICT OF INTEREST}

No potential conflict of interest relevant to this article was reported.

\section{REFERENCES}

[1] Bhardwaj A, Bhardwaj A, Misuriya A, Maroli S, Manjula S, Singh AK. Nanotechnology in dentistry: Present and future. J Int Oral Health. 2014 Feb;6(1):121-6.
[2] Website [Internet]. [cited 2020 Jun 16]. Available from: West JL, Halas NJ. Applications of nanotechnology to biotechnology [Internet]. Vol. 11, Current Opinion in Biotechnology. 2000. p. 215$7 . \quad$ Available from: http://dx.doi.org/10.1016/s09581669(00)00082-3

[3] Freitas RA Jr. Nanodentistry. J Am Dent Assoc. 2000 Nov;131(11):1559-65.

[4] Website [Internet]. [cited 2020 Jun 16]. Available from: Chandki R, Kala M, N. $\mathrm{KK}$, Brigit $\mathrm{B}$, Banthia $\mathrm{P}$, Banthia R. NANODENTISTRY: Exploring the beauty of miniature [Internet]. Journal of Clinical and Experimental Dentistry. 2012. p. e119-24. Available from: http://dx.doi.org/10.4317/jced.50720

[5] Kubik T, Bogunia-Kubik K, Sugisaka M. Nanotechnology on duty in medical applications. Curr Pharm Biotechnol. 2005 Feb;6(1):17-33.

[6] Hansrani VK, Barazanchi A, Laverty D, Brunton P. The use of direct resin composite restorations in the management of localized anterior tooth wear: A clinical update part 1 [Internet]. Vol. 46, Dental Update. 2019. p. 708-20. Available from: http://dx.doi.org/10.12968/denu.2019.46.8 .708

[7] Website [Internet]. [cited 2020 Jun 16]. Available from: Pauwels E, Kairemo K, Erba P, Bergstrom K. Nanoparticles in Cancer [Internet]. Vol. 1, Current Radiopharmaceuticalse. 2008. p. 30-6. Available from: 
http://dx.doi.org/10.2174/1874471010801

010030

[8] Website [Internet]. [cited 2020 Jun 16]. Available from: Mehta D, Guvva S, Patil M. Future impact of nanotechnology on medicine and dentistry [Internet]. Vol. 12, Journal of Indian Society of Periodontology. 2008. p. 34. Available from: http://dx.doi.org/10.4103/0972$124 x .44088$

[9] Kanaparthy R, Kanaparthy A. The changing face of dentistry: nanotechnology. Int $\mathrm{J}$ Nanomedicine. 2011 Nov 9;6:2799-804.

[10] Duraisamy R, Krishnan CS, Ramasubramanian H, Sampathkumar J, Mariappan S, Sivaprakasam AN. Compatibility of Nonoriginal Abutments With Implants [Internet]. Vol. 28, Implant Dentistry. 2019. p. 289-95. Available from:

http://dx.doi.org/10.1097/id.00000000000 00885

[11] Venugopalan S, Ariga P, Aggarwal P, Viswanath A. Magnetically retained silicone facial prosthesis. Niger $\mathrm{J}$ Clin Pract. 2014 Mar;17(2):260-4.

[12] Jyothi S, Robin PK, Ganapathy D, Anandiselvaraj. Periodontal Health Status of Three Different Groups Wearing Temporary Partial Denture [Internet]. Vol. 10, Research Journal of Pharmacy and Technology. 2017. p. 4339. Available from: http://dx.doi.org/10.5958/0974360x.2017.00795.8

[13] Ashok V, Nallaswamy D, Benazir Begum S, Nesappan T. Lip Bumper Prosthesis for an Acromegaly Patient: A Clinical Report [Internet]. Vol. 14, The Journal of Indian Prosthodontic Society. 2014. p. 279-82. Available from: http://dx.doi.org/10.1007/s13191-0130339-6

[14] Basha FYS, Ganapathy D, Venugopalan S. Oral Hygiene Status among Pregnant Women [Internet]. Vol. 11, Research Journal of Pharmacy and Technology. 2018. p. 3099. Available from: http://dx.doi.org/10.5958/0974360x.2018.00569.3

[15] Ganapathy D. Effect of Resin Bonded Luting Agents Influencing Marginal Discrepancy in All Ceramic Complete Veneer Crowns [Internet]. JOURNAL OF CLINICAL AND DIAGNOSTIC RESEARCH. 2016. Available from: http://dx.doi.org/10.7860/jcdr/2016/21447 .9028

[16] Ranganathan H, Ganapathy DM, Jain AR. Cervical and Incisal Marginal Discrepancy in Ceramic Laminate Veneering Materials: A SEM Analysis. Contemp Clin Dent. 2017 Apr;8(2):2728.

[17] Ajay R, Suma K, Ali S, Sivakumar JK, Rakshagan V, Devaki V, et al. Effect of surface modifications on the retention of cement-retained implant crowns under fatigue loads: An In vitro study [Internet]. Vol. 9, Journal of Pharmacy And Bioallied Sciences. 2017. p. 154. Available from: http://dx.doi.org/10.4103/jpbs.jpbs_146_1 7 
[18] Ariga P, Nallaswamy D, Jain AR, Ganapathy DM. Determination of Correlation of Width of Maxillary Anterior Teeth using Extraoral and Intraoral Factors in Indian Population: A Systematic Review [Internet]. Vol. 9, World Journal of Dentistry. 2018. p. 68 75. Available from: http://dx.doi.org/10.5005/jp-journals10015-1509

[19] Selvan SR, Ganapathy D. Efficacy of fifth generation cephalosporins against methicillin-resistant Staphylococcus aureus -A review. Intern Jour Contemp Microbiol. 2016;9(10):1815.

[20] Subasree S, Murthykumar K, Dhanraj. Effect of Aloe Vera in Oral Health-A Review [Internet]. Vol. 9, Research Journal of Pharmacy and Technology. 2016. p. 609. Available from: http://dx.doi.org/10.5958/0974360x.2016.00116.5

[21] Vijayalakshmi B, Ganapathy D. Medical management of cellulitis [Internet]. Vol. 9, Research Journal of Pharmacy and Technology. 2016. p. 2067. Available from: http://dx.doi.org/10.5958/0974360x.2016.00422.4

[22] Kannan A, Venugopalan S. A systematic review on the effect of use of impregnated retraction cords on gingiva [Internet]. Vol. 11, Research Journal of Pharmacy and Technology. 2018. p. 2121. Available from: http://dx.doi.org/10.5958/0974360x.2018.00393.1

[23] Ganapathy DM, Kannan A, Venugopalan S. Effect of Coated Surfaces influencing
Screw Loosening in Implants: A Systematic Review and Meta-analysis [Internet]. Vol. 8, World Journal of Dentistry. 2017. p. 496-502. Available from: $\quad$ http://dx.doi.org/10.5005/jpjournals-10015-1493

[24] Ashok V, Suvitha S. Awareness of all ceramic restoration in rural population [Internet]. Vol. 9, Research Journal of Pharmacy and Technology. 2016. p. 1691. Available from: http://dx.doi.org/10.5958/0974360x.2016.00340.1

[25] Website [Internet]. [cited 2020 Jun 16]. Available from: Garg A. Nanodentistry and Its Applications [Internet]. Textbook of Operative Dentistry. 2015. p. 511-511. Available from: http://dx.doi.org/10.5005/jp/books/12530 33

[26] Website [Internet]. [cited 2020 Jun 16]. Available from: Almusieb MNAFF, Mazen N Alruwaili Faisal. Knowledge, attitude and practice of dental students, practitioners and specialist on composite shade matching in Al-jouf, KSA [Internet]. Vol. 72, The Egyptian Journal of Hospital Medicine. 2018. p. 4017-20. Available from: http://dx.doi.org/10.21608/ejhm.2018.909 1

[27] Website [Internet]. [cited 2020 Jun 16]. Available from: Bari YA. Knowledge, Attitude and Practice Regarding Computed Tomography and Cone Beam Computed Tomography among Dental Students at Dow University of Health 
Sciences [Internet]. Vol. 2, Advances in Dentistry \& Oral Health. 2016. Available from:

http://dx.doi.org/10.19080/adoh.2016.02.5 55599

[28] Heath JR, Davis ME. Nanotechnology and cancer. Annu Rev Med. 2008;59:25165.

[29] Website [Internet]. [cited 2020 Jun 16]. Available from: Bhushan B. Introduction to Nanotechnology: History, Status, and Importance of Nanoscience and Nanotechnology Education [Internet]. Science Policy Reports. 2016. p. 1-31. Available from: http://dx.doi.org/10.1007/978-3-31931833-2 1

[30] Website [Internet]. [cited 2020 Jun 16]. Available from: Heath J. NanoSystems biology [Internet]. Vol. 5, Molecular Imaging \& Biology. 2003. p. 312-25. Available from: http://dx.doi.org/10.1016/j.mibio.2003.10. 001

[31] Website [Internet]. [cited 2020 Jun 16]. Available from: Göpel W. Nanosystems: Molecular machinery, manufacturing and computation. ByK. Eric Drexler, J. Wiley \& Sons, Chichester, UK 1992, 556 pp., hardcover, £ 19.50, ISBN 0-471-57547-X [Internet]. Vol. 5, Advanced Materials. 1993. p. 865-6. Available from: http://dx.doi.org/10.1002/adma.19930051 119

[32] Xenaki V, Marthinussen MC, Costea DE, Didilescu AC, Susin C, Cimpan MR, et al. Knowledge about nanotechnology and intention to use nanomaterials: A comparative study among dental students in Norway and Romania. Eur J Dent Educ. 2020 Feb;24(1):79-87.

[33] Iqbal MA, Ali SI, Amin F, Tariq A, Iqbal MZ, Rizwan S. La- and Mn-Codoped Bismuth Ferrite/TiC MXene Composites for Efficient Photocatalytic Degradation of Congo Red Dye. ACS Omega. 2019 May 31;4(5):8661-8.

[34] Ozak ST, Ozkan P. Nanotechnology and dentistry. Eur J Dent. 2013 Jan;7(1):14551.

[35] Retzbach A, Marschall J, Rahnke M, Otto L, Maier M. Ariga P, Nallaswamy D, Jain AR, Ganapathy DM. Determination of Correlation of Width of Maxillary Anterior Teeth using Extraoral and Intraoral Factors in Indian Population: A Systematic Review. World J Dent 2018; 9 (1):68-75. Journal of Nanoparticle Research [Internet]. [cited 2020 Jun 16]; Available from: Retzbach A, Marschall J, Rahnke M, Otto L, Maier M. Public understanding of science and the perception of nanotechnology: the roles of interest in science, methodological knowledge, epistemological beliefs, and beliefs about science [Internet]. Vol. 13, Journal of Nanoparticle Research. 2011. p. 6231-44. Available from: http://dx.doi.org/10.1007/s11051-0110582-x 